ISSN 1392-3196 / e-ISSN 2335-8947

Zemdirbyste-Agriculture, vol. 108, No. 1 (2021), p. 35-42

DOI 10.13080/z-a.2021.108.005

\title{
Assessment of Lolium perenne tetraploid clones produced from a diverse diploid breeding population
}

\author{
Sarmīte RANCĀNE ${ }^{1}$, Dainis Edgars RUN̦G̣IS², Dzidra KREIŠMANE³ \\ Ivo VĒZIS ${ }^{1}$, Aija REBĀNE${ }^{1}$, Aldis JANSONS ${ }^{1}$ \\ ${ }^{1}$ Latvia University of Life Sciences and Technologies, Research Institute of Agronomy \\ Selekcija, Skriveru novads, Latvia \\ E-mail: sarmite.rancane@1lu.lv \\ ${ }^{2}$ Latvian State Forest Research Institute "Silava" \\ Rīgas 111, Salaspils, Latvia \\ ${ }^{3}$ Latvia University of Life Sciences and Technologies, Faculty of Agriculture \\ Liela 2, Jelgava, Latvia
}

\begin{abstract}
Perennial ryegrass (Lolium perenne L.) is one of the most important forage grasses, providing high yields with excellent forage quality. The main limiting factor for increasing the cultivation area of perennial ryegrass in the Nordic-Baltic region is insufficient winter hardiness due to unstable climatic conditions as well as insufficient persistence and drought resistance. Currently, the genetic diversity of perennial ryegrass cultivars is relatively limited; therefore, developing new, highly adaptable germplasm is of high importance in the context of changing climatic conditions.

In the framework of the Nordic-Baltic Public-Private Partnership (PPP) project in pre-breeding of perennial ryegrass, 250 tetraploid plants (hereinafter genotypes), created by chromosome doubling using colchicine at the Institute of Agriculture, Lithuanian Research Centre for Agriculture and Forestry, were evaluated in open field conditions at the Research Institute of Agronomy of Latvia University of Life Sciences and Technologies. Detailed phenological scoring of all genotypes was performed over a three-year (2016-2018) period. For data analysis, the plants were grouped according to heading time and growth habit. Significant differences among the groups were found in winterhardiness, regrowth rate, development rate of generative shoots, susceptibility to rust, etc. The seed from plants that survived well and showed some promising properties were harvested in the $2^{\text {nd }}$ ley year - a total of 199 genotypes or 358 individuals ( $80 \%$ and $48 \%$ of all, respectively).

Results of genotyping of randomly selected genotypes with the highest and lowest winter hardiness showed that the clones were genetically differentiated from the cultivars developed in Baltic countries - unique alleles were found in the tetraploid clones that were not present in the analysed cultivars. This suggests that these developed tetraploid clones or genotypes could provide valuable breeding material to improve the suitability of perennial grass cultivars to local environmental conditions in the future.
\end{abstract}

Key words: DNA markers, genotype, perennial ryegrass, phenotyping, pre-breeding, cultivar.

\section{Introduction}

Milder winters and increase in the length of growing seasons provide opportunities for the cultivation of forage grasses, which have previously been limited in northern latitudes. One of these species is perennial ryegrass (Lolium perenne L.), the proportion of which is increasing in seed mixtures used for forage grass production.

Perennial ryegrass is a very important component in forage production in more maritime regions south of $60^{\circ} \mathrm{N}$, because of its high dry matter yield, regrowth capacity and excellent forage quality (Kemešyte et al., 2016; Berzins et al., 2018 b). It is a widely used forage species in temperate regions of the world, particularly in Western Europe, including Denmark, Ireland and United Kingdom (Deleuran, Boelt, 2009; Grogan, Gilliland, 2011; McDonagh et al., 2016). Perennial ryegrass is also successfully grown in the southern parts of Sweden in mixtures with other grasses. Norwegian studies have concluded that the inclusion of perennial ryegrass increases yield and digestibility as well as decreases weeds in the first year, both in the warmer southern regions as well as in more northerly regions (Jørgensen et al., 2019). Climate change scenarios predict that in the

Please use the following format when citing the article:

Rancāne S., Ruṇgis D. E., Kreišmane D., Vēzis I., Rebāne A., Jansons A. 2021. Assessment of Lolium perenne tetraploid clones produced from a diverse diploid breeding population. Zemdirbyste-Agriculture, 108 (1): 35-42. DOI 10.13080/z-a.2021.108.005 
near future, the cultivation range of perennial ryegrass will expand northwards. With its high biomass yield, regrowth capacity and superior feed quality perennial ryegrass will undoubtedly become a promising forage crop at higher latitudes experiencing prolonged growing seasons and milder winters (Helgadóttir et al., 2014).

However, large-scale cultivation of this species in Baltic and Nordic conditions still tends to be relatively risky (Wilkins, Humphreys, 2003; Østrem et al., 2013; Berzins et al., 2015). Perennial ryegrass grown inland and north of $60^{\circ} \mathrm{N}$ generally shows poor survival because of extensive winter damage (Helgadóttir et al., 2018). Due to unstable wintering conditions in the Baltic region and extreme fluctuations in temperature during spring, perennial ryegrass tends to disappear from swards, especially in the $2^{\text {nd }}$ and subsequent ley years (Lemežiené et al., 2004; Berzins et al., 2018 b). To reduce the risks for ryegrass cultivation in these regions and to expand production into new areas, it is necessary to develop improved perennial ryegrass germplasm and first of all to select a range of traits within different germplasm types, varying in ploidy, heading time, growth habit, etc. The main challenge for breeders is to increase winter hardiness, survival, drought resistance and other traits significant for Northern Europe in the context of climate change (Rognli et al., 2018; Rancane et al., 2019). Therefore, it is important to evaluate the available genetic resources of perennial ryegrass in addition to other breeding tools, e.g., production of tetraploid germplasm.

Drought resistance is also increasing in importance, and phenotyping in combination with genomic tools could improve the assessment of perennial ryegrass breeding material. Plant recovery after drought periods is an important trait, and there is a clear effect of ploidy level on recovery after drought stress (Lee et al., 2019). One explanation for this is that at comparable drought stress levels, tetraploid plants showed signs of senescence one week later than diploid plants. Other possible reasons are differences in stomatal architecture of tetraploid plants, enhanced water use efficiency or accumulation of storage carbohydrates (Westermeier, Hartmann, 2019).

Within the Nordic-Baltic public-private partnership, new and commercial perennial ryegrass populations and genotypes were assessed in differing environmental and climatic conditions. Growing conditions in Northern Europe are unique with different day length, temperature fluctuations, frost and thaw conditions, etc. in comparison to other cultivation regions. Therefore, to increase the cultivation of perennial ryegrass and use in grass mixtures in Northern Europe, germplasm must be selected to be adapted to these specific environmental and climatic conditions (Helgadóttir et al., 2014; 2016; Østrem et al., 2015 a). It would be desirable to breed material with as wide adaptation as possible, so that the material can be used safely in different climatic conditions, especially in view of the rapidly changing wintering conditions in the Nordic-Baltic region. Such an approach would require considerable pre-breeding efforts in line with the already initiated Nordic PublicPrivate Partnership for pre-breeding in perennial ryegrass (Rognli et al., 2013).

Tetraploid perennial ryegrass genotypes induced from a diploid population were analysed in this study with the aim of obtaining detailed phenotypic information on tetraploid genotypes in different growing seasons. The plants were grouped according to heading time and growth habit. Several other significant phenotypic differences between these groups were identified indicating that this material is promising for further breeding efforts. A subset of individuals was analysed with genetic markers to compare these novel tetraploid genotypes with previously developed Baltic perennial ryegrass cultivars.

\section{Materials and methods}

Perennial ryegrass (Lolium perenne L.) tetraploids were induced at the Institute of Agriculture, Lithuanian Research Centre for Agriculture and Forestry by chromosome doubling of the broad diploid breeding population using colchicine. Previously results indicated that there is high genetic variability in the diploid population, therefore, seeds from four $2^{\text {nd }}$ generation seed lots were randomly selected for doubling. Seed-excised embryos were treated with colchicine with subsequent culture in vitro (Dabkevičienè, 2009).

Field trials. Induced tetraploids were evaluated in field trials at the Research Institute of Agronomy $\left(56^{\circ} 37 \mathrm{~N}, 25^{\circ} 07 \mathrm{E}\right)$ of Latvia University of Life Sciences and Technologies. In June 2016, 250 tetraploid plantlets (hereinafter genotypes) were placed in pots with peat substrate and grown before cloning for approximately two months. At the end of August, the genotypes were cloned and planted in a completely randomised design in three replicates in sod-podzolic loamy sand soil Eutric Retisol (WRB, 2014) with $\mathrm{pH}_{\mathrm{KCl}} 5.7$, organic matter $18 \mathrm{~g} \mathrm{~kg}^{-1}$, plant available phosphorus $\left(\mathrm{P}_{2} \mathrm{O}_{5}\right) 66 \mathrm{mg} \mathrm{kg}^{-1}$ and potassium $\left(\mathrm{K}_{2} \mathrm{O}\right) 69 \mathrm{mg} \mathrm{kg}^{-1}$. Individuals were planted in a $60 \times 60 \mathrm{~cm}$ grid.

Phenological and phenotypic evaluations were carried out repeatedly over a three-year (2016-2018) period. This study evaluated a number of features: growth habit, leaf width, rust susceptibility (all these features were re-evaluated over the experimental period), winter hardiness, regrowth in spring and after harvesting, tillering density, plant height (in 2017 and 2018), fresh matter per plant (in 2017), dry matter yield and seed weight per plant (in 2018). Phenotypic properties were scored on a 9-point scale with lower scores indicating weaker expression and higher scores showing a more pronounced expression of the trait. For example, a score of 1 for winter hardiness indicated that the individual was very weak and barely survived overwintering, while a score of 9 indicated that the individual did not show any signs of damage during overwintering. Growth habit was assessed according to UPOV (2006) guidelines: 1 - erect $\left(\sim 80-90^{\circ}\right), 3-$ semi-erect $\left(70-75^{\circ}\right), 5-$ medium $\left(\sim 45^{\circ}\right)$, 7 - semi prostrate $\left(20-25^{\circ}\right), 9$ - prostrate $\left(<15^{\circ}\right)$.

Rust susceptibility was assessed according to the EUCARPIA Multisite Rust evaluation methodology (Schubiger et al., 2010). A scale from 1 to 9 was used: 1 - no rust disease, 2 - traces of rust, $3-5 \%$ of the leaf surface is covered with rust pustules, $4-10 \%, 5-25 \%$, $6-40 \%, 7-60 \%, 8-75 \%, 9-$ more than $75 \%$ of the foliage covered with rust, dominated by necrotic leaves. The rating values represented a relative estimate of leaf area occupied by rust pustules. Rust susceptibility was scored for the first time in 2016, when due to atypically warm and humid weather conditions in mid-September, part of the genotypes were heavily infected shortly after planting in the field. In the following years, the rust susceptibility was scored several times a season, if necessary. During the interpretation of the obtained data, the rust susceptibility was recalculated to the rust resistance, because the task is to select a material with a higher rust resistance. 
Regrowth rate was assessed visually by comparing the growth rate of genotypes in spring after vegetation resumption and after mowing. To find out differences between genotypes in terms of plant height increase over a certain period, the tallest stem was measured at the heading-flowering stage (on $21^{\text {st }}$ and $27^{\text {th }}$ of June, 2017), and the differences were calculated. Leaf width and intensity of ear formation at the headingflowering stage were also assessed visually using a 9-point scale. Heading time i.e. the date, when the first three tillers emerge was fixed. Twice (at $1^{\text {st }}$ and $2^{\text {nd }}$ cut) during the vegetation period in the $1^{\text {st }}$ ley year (2017), an assessment of above ground plant mass was done by cutting each plant individually during full heading. In the $2^{\text {nd }}$ ley year (2018), all surviving plants were cut, and the weight of dried straw and seeds of each plant was determined.

Genetic analysis. Agronomic properties and genetic diversity sub-set of six tetraploid genotypes were compared to five perennial ryegrass cultivars developed in the Baltic countries. Two of the cultivars are tetraploid intermediate '(Elena DS' and 'Raite'), two are tetraploid late type ('Spidola' and 'Raminta'), and one cultivar is diploid intermediate type ('Gunta'). In the spring of the $2^{\text {nd }}$ ley year, three tetraploid genotypes (Vg169, Vg26 and Vg213) were randomly chosen from among the best wintering clones, and three (As204, Vg144 and Vg149) from the poorest overwintering clones. Dry matter yield, winter hardiness, heading date, ear formation and rust resistance were assessed over four years in continuous sowing for the cultivars and over two years for the tetraploid clones.

Sward cover was assessed in the $4^{\text {th }}$ ley year for the cultivars; an assessment of the overall condition of clones was performed in the $2^{\text {nd }}$ ley year. Genetic analyses were done on 12 individuals from each of five cultivars, and one individual of six selected tetraploid clones (Table 4). DNA was extracted from a leaf sample from a single individual using a CTAB-based method (Porebski et al., 1997). Genotyping was done using eight simple sequence repeat (SSR) markers: G03 020, G05 033, G07_037, G01_053, G07_065, G05_071̄, G05_08 and G05 099 (Studer et al., 2008). Each forward primer was labēlled with a different fluorophore (6-FAM, HEX or TMR) to facilitate visualization using capillary electrophoresis. The polymerase chain reactions (PCRs) were carried out in a $10 \mu \mathrm{l}$ solution, containing $2 \mu \mathrm{L} \mathrm{Hot}$ FirePol Blend MasterMix (Soltis BioDyne, Estonia) with $10 \mathrm{mM} \mathrm{MgCl}, 0.5 \mu \mathrm{M}$ of each primer, $2 \mu \mathrm{L}$ (approximately $50 \mathrm{ng}$ ) DNA solution. The PCR cycling conditions were: $95^{\circ} \mathrm{C}$ for $15 \mathrm{~min}, 40$ cycles of $95^{\circ} \mathrm{C}$ for $20 \mathrm{~s}, 58^{\circ} \mathrm{C}$ for $30 \mathrm{~s}$ and $72^{\circ} \mathrm{C}$ for $45 \mathrm{~s}$, followed by $72^{\circ} \mathrm{C}$ for $5 \mathrm{~min}$. The PCR products were size separated on an ABI 3130xl Genetic Analyzer (Applied Biosystems, USA) and genotyped using software GeneMapper, version 4.0 (Applied Biosystems). As the analysed tetraploid clones and cultivars were derived from diploid germplasm, the utilised SSR loci were scored and analysed as diploid. Genetic diversity parameters were calculated using software GenAlEx, version 6.0 (Peakall, Smouse, 2006). Neighbour-joining trees and consensus trees were constructed using the programs Neighbour and Consense in PHYLIP (Felsenstein, 1989). Phylogenetic trees were visualized using software FigTree, version 1.4.2 (http:// tree.bio.ed.ac.uk/software/figtree/).

Meteorological conditions. During the winter 2017-2018 in general, the temperature was higher than the long-term average, but there were sharp fluctuations: unusually warm conditions in December and January were followed by sharp cold periods in February. As a result of it, the average air temperature in February and March was below long-term average: $-3.5^{\circ} \mathrm{C}$ and $-2.1^{\circ} \mathrm{C}$, respectively. In the second half of the year 2017, heavy rains followed one another; the monthly precipitation rate was significantly exceeded. The atypically wet season in 2017 was followed by an intensified drought in 2018, when precipitation during the whole vegetation period from May to September was well below the norm - in some months the precipitation was 2-3 times less compared to the long-term average. Along with the limited amount of humidity, long periods of heat prevailed: from April to October the average monthly temperature was $+2 \ldots+4^{\circ} \mathrm{C}$ above long-term average (Fig. 1).

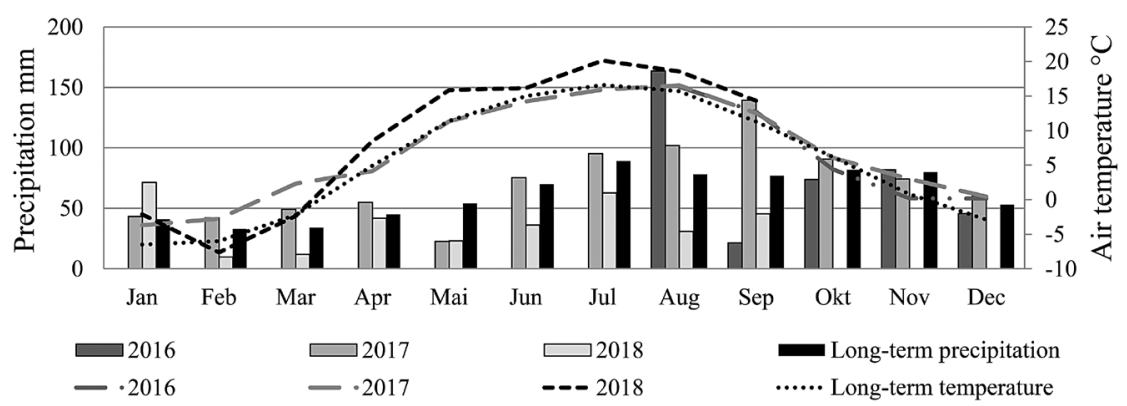

Figure 1. Air temperature and precipitation by months in 2016-2018 and long-term averages

Statistical analysis. The perennial ryegrass genotypes were divided into several groups according to phenological and phenotypic properties. Genotypes were divided into two groups according to heading time calculating from $1^{\text {st }}$ May: intermediate (IM) (flowering prior to day 33, including) and late (L) (flowering after day 34 , including). Two groups were defined for growth habit: erect $\left(>45^{\circ}\right)(\mathrm{E})$ and prostrate $\left(<45^{\circ}\right)(\mathrm{P})$. Based on these initial groupings, individuals were further divided into four sub-groups combining heading time and growth habit: intermediate-erect (IM-E), intermediate-prostrate (IM-P), late-erect (L-E) and late-prostrate (L-P). The number of genotypes in each group is not completely identical, as the mean scores were taken into account and genotypes with the same scores were not divided into different groups. All genotypes survived during three years were grouped: a) non-persistent (G0) - genotypes with no seed collected, b) weak persistent (G1) - genotypes with one plant survived, c) well persistent (G2) - genotypes with two plants survived, and d) excellent persistent (G3) - genotypes with all three plants survived. Two groups were formed for further analysis: weak persistent group (G0/G1), which combined non-persistent and weak persistent, and persistent group $(\mathrm{G} 2 / \mathrm{G} 3)$, which combined well and excellent persistent genotypes. Results were analysed by ANOVA with a significance level of 0.05 . 
For the analyses of data obtained, the test of statistically significant differences $\left(\mathrm{LSD}_{0.05}\right)$ and the Fisher criterion $(F$-test) were used.

\section{Results and discussion}

The tetraploid genotypes were phenologically diverse with flowering time ranging from 28 to 48 days (calculated from the $1^{\text {st }}$ of May). Due to increased rainfall in July and August in trial establishment year (2016), cloning and planting in the field was delayed for almost a month. The winter of 2017 was favourable; therefore, no winter damage in the $1^{\text {st }}$ ley year was found for most of the plants. Environmental conditions in the $2^{\text {nd }}$ ley year were favourable for the assessment of winter hardiness and drought resistance. There were sharp temperature fluctuations during winter and spring and reduced precipitation during vegetation, which was combined with prolonged heat periods (Fig. 1).

To obtain a diverse range of genotypes for breeding, seeds were collected from all individuals that had good or satisfactory winter hardiness. In total, seeds were collected from 196 genotypes $(80 \%$ of all genotypes), represented by 358 individual plants $(48 \%$ of all individual plants). Of the 250 assessed genotypes, seeds were collected from 2 or 3 individuals for 121 genotypes $(48.5 \%)$. Seeds from 76 genotypes $(30.5 \%)$ were collected from only one individual, as the other two replicates were severely damaged over winter or did not survive due to various reasons. Seeds were not collected from 53 genotypes $(21.2 \%)$, as they did not survive in any of the replicates (Table 1$)$.

Table 1. Number of perennial ryegrass genotypes by group and averages within groups

\begin{tabular}{|c|c|c|c|c|c|c|}
\hline \multirow{2}{*}{$\begin{array}{l}\text { Group, } \\
\text { number of genotype }\end{array}$} & \multirow{2}{*}{$\begin{array}{c}\text { Number of genotypes } \\
\text { survived } \\
\text { for } 3 \text { years }\end{array}$} & \multirow{2}{*}{$\begin{array}{l}\text { Height } \\
\text { increase } \\
\mathrm{cm}\end{array}$} & \multicolumn{2}{|c|}{$\begin{array}{c}\text { Fresh matter per plant (2017) } \\
\text { kg }\end{array}$} & \multicolumn{2}{|c|}{$\begin{array}{c}\text { Average yield per plant survived } \\
\text { for } 3 \text { years g }\end{array}$} \\
\hline & & & $1^{\text {st }}$ cut & $2^{\text {nd }}$ cut & dry matter & seed \\
\hline IM, 126 & 103 & 0.6 & 0.66 & 0.39 & 54.6 & 11.3 \\
\hline L, 124 & 93 & $3.6^{*}$ & $0.77 *$ & $0.45 *$ & 51.1 & 10.0 \\
\hline $\mathrm{LSD}_{0.05}$ & & 0.81 & 0.05 & 0.03 & 10.13 & 2.10 \\
\hline $\mathrm{E}, 126$ & 91 & 2.0 & 0.72 & 0.43 & 46.2 & 9.6 \\
\hline P, 124 & 105 & 2.2 & 0.70 & 0.42 & $59.4 *$ & $11.7 *$ \\
\hline $\mathrm{LSD}_{0.05}$ & & 0.81 & 0.05 & 0.03 & 10.13 & 2.10 \\
\hline IM-E, 61 & 46 & 0.7 & 0.67 & 0.4 & 46.4 & 10.1 \\
\hline IM-P, 65 & 57 & 0.5 & 0.65 & 0.38 & $62.3 *$ & 12.4 \\
\hline $\mathrm{LSD}_{005}$ & & 1.15 & 0.07 & 0.05 & 14.27 & 2.96 \\
\hline L-E, 65 & 45 & 3.4 & 0.78 & 0.45 & 46.1 & 9.0 \\
\hline L-P, 59 & 48 & 3.9 & 0.76 & 0.45 & 56.6 & 11.0 \\
\hline $\mathrm{LSD}_{0.05}$ & & 1.16 & 0.07 & 0.05 & 14.39 & 2.99 \\
\hline G0, 53 & 0 & 3.3 & 0.69 & 0.42 & & \\
\hline $\mathrm{G} 1,76$ & 76 & 1.9 & 0.69 & 0.41 & 64.3 & 11.6 \\
\hline $\mathrm{G} 2 / 3,121$ & 121 & 1.6 & 0.74 & 0.43 & $68.7 *$ & $14.7 *$ \\
\hline $\mathrm{LSD}_{0.05} 1$ & & 1.11 & 0.07 & 0.05 & 10.34 & 2.16 \\
\hline $\mathrm{LSD}_{0.05}{ }^{2}$ & & 1.02 & 0.06 & 0.04 & 9.51 & 1.99 \\
\hline Min & & 0.5 & 0.13 & 0.08 & 9.1 & 2.0 \\
\hline Max & & 14.5 & 1.54 & 0.82 & 333.0 & 53.5 \\
\hline
\end{tabular}

Note. IM - intermediate, $\mathrm{L}$ - late, $\mathrm{E}$ - erect, $\mathrm{P}$ - prostrate; IM-E - intermediate-erect, IM-P - intermediate-prostrate, $\mathrm{L}$-E - late-erect, L-P - late-prostrate; G0 - non-persistent, G1 - weak persistent, G2 - well persistent, G3 - excellent persistent; least significant difference: $\mathrm{LSD}_{0.05}{ }^{1}$ - between groups $\mathrm{G} 0$ and $\mathrm{G} 1, \mathrm{LSD}_{0.05}{ }^{2}$ - between groups $\mathrm{G} 0$ and $\mathrm{G} 2 / 3$; * - indicate to the significant differences between groups.

Regrowth rate between genotypes varied widely with scores ranging from 1.6 to 8.0 in spring and from 1.8 to 8.7 after mowing. Early genotypes had significantly higher $(p<0.05)$ regrowth intensity in spring and after mowing (Table 2). However, plant growth (height increase) at the end of June (heading of late genotypes, flowering of early genotypes) was significantly higher $(p<0.05)$ in late genotypes due to their longer vegetation period. In addition, late genotypes formed denser shoots and had higher green mass yield at both cuts. Average green mass yield per genotype in the $1^{\text {st }}$ ley year ranged between $0.13-1.54 \mathrm{~kg}$ at the $1^{\text {st }}$ cut and $0.08-0.82 \mathrm{~kg}$ at the $2^{\text {nd }}$ cut.

High diversity was observed in growth habit from almost erect growing genotypes (scored 2-3) to prostrate types (score 8 ). The majority of individuals $(62 \%)$ with shoots growing from the base of tillers at an angle of $45-60^{\circ}$ had an intermediate growth habit. One-third (32\%) of genotypes had a tendency to form more prostrate sward, and only about $6 \%$ of genotypes were rated as erect type with a shoot angle of $70-90^{\circ}$. This range of phenotypic variation enables selection of genotypes for different purposes. For example, more erect types are preferable for mowing, while more prostrate types are useful for grazing and ornamental lawns. In general, earlier genotypes had a more vertical growth habit; however, significant differences in growth habit were not found between the intermediate and late genotype groups (Table 2).

Usually, survival of perennial ryegrass in the first winter is good, and differences between genotypes and cultivars appear in subsequent years (Berzins et al., 2018 a). This was confirmed by previous studies within the Baltic region (Lemežienè et al., 2004; Aavola, 2005) as well as in our experiment. Weak winter hardiness (with a score of $<5$ ) was observed in only four genotypes in the $1^{\text {st }}$ year but in 98 genotypes in the $2^{\text {nd }}$ year. The number of genotypes with a winter hardiness score of $>7$ was 182 and 47 in the $1^{\text {st }}$ and $2^{\text {nd }}$ year, respectively. Prostrate genotypes had significantly better $(p<0.05)$ winter hardiness in the $2^{\text {nd }}$ year (Table 2), and within the prostrate growth habit group late genotypes were more winter hardy. Prostrate genotypes had higher seed yield (Table 1) and higher growth intensity in spring and wider leaves (Table 2).

Of all the genotypes, from which seeds were collected, the largest proportion was from the intermediateprostrate (IM-P) sub-group. Apparently, genotypes from this group cease growth earlier in the autumn, are better prepared for wintering and, therefore, are more tolerant of temperature fluctuations and other stresses in winter and early spring. It has been observed that non-native species 
Table 2. Phenotypic grouping and scores (1-9) of perennial ryegrass genotypes

\begin{tabular}{|c|c|c|c|c|c|c|c|c|c|}
\hline \multirow{2}{*}{ Group } & \multirow{2}{*}{$\begin{array}{c}\text { Growth } \\
\text { habit }\end{array}$} & \multirow{2}{*}{$\begin{array}{c}\text { Density } \\
\text { of ears }\end{array}$} & \multirow{2}{*}{$\begin{array}{l}\text { Leaf } \\
\text { width }\end{array}$} & \multicolumn{2}{|c|}{ Winter hardiness } & \multicolumn{2}{|c|}{ Rust resistance } & \multicolumn{2}{|c|}{ Regrowth } \\
\hline & & & & $1^{\text {st }}$ year & $2^{\text {nd }}$ year & $1^{\text {st }}$ year & $2^{\text {nd }}$ year & in spring & aftermath \\
\hline IM & 5.6 & $6.8^{*}$ & 6.8 & 7.3 & 5.4 & 6.5 & 6.3 & $5.0^{*}$ & $5.4^{*}$ \\
\hline L & 5.2 & 4.9 & 6.9 & 7.3 & 5.1 & 6.8 & 6.7 & 4.6 & 4.9 \\
\hline $\mathrm{LSD}_{005}$ & 0.14 & 0.36 & 0.27 & 0.21 & 0.40 & 0.41 & 0.36 & 0.37 & 0.38 \\
\hline $\mathrm{E}$ & 4.6 & 5.9 & 6.7 & $7.5 *$ & 4.9 & 6.7 & 6.4 & 4.6 & $5.4^{*}$ \\
\hline $\mathrm{L}$ & $6.2 *$ & 5.8 & $7.0^{*}$ & 7.1 & $5.6^{*}$ & 6.6 & $\begin{array}{l}0.4 \\
6.6\end{array}$ & $5.1^{4} *$ & 5.0 \\
\hline $\mathrm{LSD}_{0.5}$ & 0.14 & 0.36 & 0.27 & 0.21 & 0.40 & 0.41 & 0.36 & 0.37 & 0.38 \\
\hline IM-E & 4.8 & 6.9 & 6.6 & $7.5^{*}$ & 5.1 & 6.3 & 6.1 & 4.8 & 5.6 \\
\hline IM-P & $6.3^{*}$ & 6.8 & 6.9 & 7.2 & 5.6 & 6.7 & 6.5 & 5.2 & 5.2 \\
\hline $\mathrm{LSD}_{005}$ & 0.20 & 0.51 & 0.38 & 0.29 & 0.57 & 0.58 & 0.51 & 0.52 & 0.54 \\
\hline L-E & 4.5 & 4.9 & 6.7 & 7.4 & 4.7 & 7.0 & 6.7 & 4.3 & 5.1 \\
\hline L-P & $6.1 *$ & 4.9 & $7.1 *$ & 7.1 & $5.6^{*}$ & 6.6 & 6.7 & $4.9^{*}$ & 4.7 \\
\hline $\mathrm{LSD}_{0.05}$ & 0.20 & 0.52 & 0.38 & 0.29 & 0.57 & 0.58 & 0.52 & 0.52 & 0.54 \\
\hline G0 & 5.1 & 5.2 & 6.4 & 7.2 & 3.3 & 7.0 & 6.7 & 3.1 & 5.6 \\
\hline G1 & 54 & $6.0 *$ & 6.6 & 7.3 & 5.0 & 6.5 & 6.5 & $47 *$ & 52 \\
\hline $\mathrm{G} 2 / 3$ & 56 & $6.1 *$ & 7.2 & 7.4 & 6.2 & 6.6 & 6.5 & $5.6 *$ & 49 \\
\hline $\mathrm{LSD}_{005}{ }^{1}$ & 0.34 & 0.49 & 0.35 & 0.28 & 0.40 & 0.57 & 0.50 & 0.38 & 0.52 \\
\hline $\mathrm{LSD}_{0.05}{ }^{2}$ & 0.31 & 0.45 & 0.33 & 0.26 & 0.37 & 0.52 & 0.46 & 0.35 & 0.48 \\
\hline Min & 2.0 & 2.0 & 3.0 & 3.2 & 1.3 & 2.0 & 3.2 & 1.6 & 1.8 \\
\hline Max & 8.0 & 9.0 & 9.0 & 8.7 & 8.3 & 9.0 & 7.8 & 8.0 & 8.7 \\
\hline
\end{tabular}

Explanation under Table 1

in the Nordic region do not cease growth in the autumn early enough for successful acclimation to the wintering condition. Studies in Norway (Østrem et al., 2015 b) have shown that in the north, the amount of light could be insufficient to trigger the changes in photosynthetic apparatus that are responsible for growth cessation. It is important to pay more attention to selecting genotypes with photoperiodically-controlled growth cessation in the autumn and a less rapid resumption of development in the spring, especially in the context of expected climate changes in the Nordic-Baltic region.

Genotypes with a more erect growth habit had significantly higher $(\mathrm{p}<0.05)$ aftermath regrowth intensity and had denser tillering compared to prostrate forms (Table 2). Tetraploid perennial ryegrass individuals usually have wide, dark green leaves. Approximately $40 \%$ of genotypes were characterised as having wide leaves (score $>7)$, and 38 genotypes $(15 \%)$ had very wide leaves (score $>8$ ).

Lengthy dry periods, which influence yield, have become more frequent in recent years. The effect of drought on the growth and development of perennial ryegrass has been previously observed in studies throughout Europe. The general conclusion is that tetraploid cultivars are more drought resistant than diploid cultivars, but that drought resistance in general is low due to the shallow root system of perennial ryegrass (Westermeier et al., 2019). The vegetation period in 2018 was exceptionally hot and dry, which influenced the overall vitality of perennial ryegrass genotypes and fresh yield. Nevertheless, at seed harvest, differences were observed between genotypes for plant height and dry weight, ranging from 9.1 to $333.0 \mathrm{~g}$ (Table 1 ). Weight of dried plant for 47 genotypes $(23 \%)$ ranged from 9 to $49 \mathrm{~g}, 129$ genotypes (65\%) 50-99 g, 19 genotypes $(10 \%) 100-146 \mathrm{~g}$, and for 4 genotypes was over $150 \mathrm{~g}$. Average plant dry weight at seed harvest and seed yield were not significantly different between intermediate and late genotype groups. However, prostrate genotypes had significantly higher $(p<0.05)$ yield of both dry matter and seed compared to erect genotypes. Seed weight ranged from 2 to $53.5 \mathrm{~g}$ with 71 genotypes $(36 \%)$ having low seed yield $(2-10 \mathrm{~g}), 106$ genotypes average seed yield $(11-20 \mathrm{~g})$ and 22 genotypes (11\%) high yield (21-54 g).

Rust infection is a significant problem for perennial ryegrass. Crown rust, caused by Puccinia coronata, has a significant impact on yield, feed quality and digestibility; therefore, breeding for resistance is important.

The use of rust resistant parental genotypes in pre-breeding was one of the objectives of this study. The autumn of the year, when clones were established, was atypically warm and moist, and, as a result, some of the clones were heavily infected by rust, which usually does not occur in the first year. However, some of the clones did not show signs of rust infection, and overall rust resistance scores ranged from 2 to 9 (Table 2). No significant differences between groups were identified. The following year, rust resistance of genotypes ranged from 3.2 to 7.8. However, no correlations were identified between the groups or between the two experimental years. This indicates that different rust races are present in different years, against which the resistance of individual genotypes varies greatly, and, therefore, observations for several years and at several locations appear to be the best way to improve rust resistance in perennial ryegrass (Reheul, Ghesquiere, 2006). Studies in Lithuania have concluded that the prevalence and degree of infection of crown rust were strongly influenced by weather conditions during the year of study, but the resistance of locally grown perennial ryegrass cultivars also played an important role (Kemešytè et al., 2019).

Comparison of agronomic properties and genetic diversity of six tetraploid genotypes to five perennial ryegrass cultivars (including four tetraploid and one diploid) developed in the Baltic countries showed some essential differences (Table 3).

Overall, winter hardiness of the cultivars was good - average scores over the four years ranged from 4.5 to 6.9. The 'Elena DS' had a significantly lower $(p<0.05)$ winterhardiness score (4.5) compared to the othercultivars. Nevertheless, this cultivar shows excellent renewal in sward, which is usually characteristic of Festulolium hybrids (Berzins et al., 2019). Of the assessed cultivars, 'Elena DS' was the earliest, and it is possible that rapid development in spring enables effective use of moisture collected in soil over winter and efficient renewal of this cultivar. In addition, intensive regrowth of this cultivar after mowing and very intensive culm formation in aftermath compensated for losses caused by weak winter hardiness. Significant differences $(p<0.05)$ between the tetraploid clones were found for winter hardiness (scores ranged from 2.8 to 7.8 ) as well as heading date (ranging from day 30 to 37 ). Long-term observations indicate 
Table 3. Agronomic properties of perennial ryegrass cultivars and tetraploid clones

\begin{tabular}{|c|c|c|c|c|c|c|}
\hline Cultivar & $\begin{array}{l}\text { Winter } \\
\text { hardiness } \\
(1-9)^{1}\end{array}$ & $\begin{array}{l}\text { Dry matter yield } \\
\mathrm{t} \mathrm{ha}^{-1}\end{array}$ & $\begin{array}{c}\text { Heading } \\
\text { date }^{2}\end{array}$ & $\begin{array}{l}\text { Culms in aftermath } \\
(1-9)^{3}\end{array}$ & $\begin{array}{l}\text { Rust resistance } \\
\qquad(1-9)^{4}\end{array}$ & $\begin{array}{l}\text { Cover } \\
(1-9)^{5}\end{array}$ \\
\hline Elena DS & 4.5 & $7.65 \mathrm{a}$ & $32 \mathrm{~b}$ & $7.0 \mathrm{a}$ & $6.6 \mathrm{a}$ & $2.5 \mathrm{c}$ \\
\hline Gunta & $6.2 \mathrm{a}^{*}$ & $6.12 \mathrm{~b}$ & $33 \mathrm{~b}$ & $5.3 \mathrm{~b}$ & $6.0 \mathrm{a}$ & $3.2 \mathrm{c}$ \\
\hline Raite & $6.5 \mathrm{a}$ & $6.76 \mathrm{~b}$ & $35 \mathrm{ab}$ & $4.6 \mathrm{~b}$ & $6.4 \mathrm{a}$ & $4.5 \mathrm{ab}$ \\
\hline Raminta & $6.9 \mathrm{a}$ & $6.88 \mathrm{ab}$ & $36 \mathrm{a}$ & $5.9 \mathrm{ab}$ & $5.9 \mathrm{a}$ & $5.5 \mathrm{a}$ \\
\hline Spidola & $6.3 \mathrm{a}$ & $6.26 \mathrm{~b}$ & $37 \mathrm{a}$ & $5.2 \mathrm{~b}$ & $6.3 \mathrm{a}$ & $5.8 \mathrm{a}$ \\
\hline $\mathrm{LSD}_{0.05}$ & 1.98 & 1.09 & 2.7 & 1.43 & 1.02 & 1.07 \\
\hline Clone & $\begin{array}{c}\text { Winter } \\
\text { hardiness } \\
(1-9)^{1}\end{array}$ & $\begin{array}{l}\text { Fresh matter } \\
\text { kg plant }^{-1}\end{array}$ & $\begin{array}{l}\text { Heading } \\
\text { date }^{2}\end{array}$ & $\begin{array}{l}\text { Culms in aftermath } \\
\qquad(1-9)^{3}\end{array}$ & $\begin{array}{l}\text { Rust resistance } \\
\qquad(1-9)^{4}\end{array}$ & $\begin{array}{c}\text { Overall } \\
\text { assessment }(1-9)^{6}\end{array}$ \\
\hline As204s0 & $2.8 \mathrm{c}$ & $1.22 \mathrm{~b}$ & $30 \mathrm{~b}$ & $5.0 \mathrm{~b}$ & $6.9 \mathrm{a}$ & $1.7 \mathrm{~b}$ \\
\hline Vg169 & $7.8 \mathrm{a}$ & $1.16 \mathrm{~b}$ & $33 \mathrm{~b}$ & $8.0 \mathrm{a}$ & $5.7 \mathrm{a}$ & $8.3 \mathrm{a}$ \\
\hline $\mathrm{Vg} 144 \mathrm{~s} 0$ & $2.8 \mathrm{c}$ & $1.28 \mathrm{a}$ & $34 \mathrm{ab}$ & $3.3 \mathrm{~b}$ & $6.7 \mathrm{a}$ & $1.3 \mathrm{~b}$ \\
\hline Vg26 & $7.7 \mathrm{a}$ & $1.08 \mathrm{~b}$ & $36 \mathrm{ab}$ & $5.7 \mathrm{~b}$ & $4.5 \mathrm{a}$ & $6.3 \mathrm{a}$ \\
\hline Vg149 & $4.3 \mathrm{bc}$ & $1.76 \mathrm{a}$ & $36 \mathrm{ab}$ & $8.0 \mathrm{a}$ & $5.8 \mathrm{a}$ & $4.3 \mathrm{~b}$ \\
\hline Vg213 & $6.2 \mathrm{ab}$ & $1.18 \mathrm{~b}$ & $37 \mathrm{a}$ & $5.0 \mathrm{~b}$ & $6.2 \mathrm{a}$ & $5.3 \mathrm{a}$ \\
\hline $\mathrm{LSD}_{0.05}$ & 2.64 & 0.48 & 3.17 & 1.94 & 2.72 & 3.93 \\
\hline
\end{tabular}

Note. ${ }^{1}-1$ - very weak, almost all plant/sward is damaged, 9 - excellent, without damage; ${ }^{2}-$ when the first three ears have appeared, day from the $1^{\text {st }}$ May; ${ }^{3}-1$ - absent, 2 - few, 9 - numerous; ${ }^{4}-1$ - more than $75 \%$ of the foliage covered with rust, dominated by necrotic leaves, 9 - no rust disease; ${ }^{5}-$ sward cover in the $5^{\text {th }}$ ley year: $1-$ about $10 \%, 9-$ about $90 \%$; ${ }^{6}-1-$ very weak, 1 - excellent; * - different letters indicate significant differences between them; identical letters indicate that there are no significant differences between them; the letter is not placed if the number differs significantly from all of other.

that perennial ryegrass has good overwintering capacity in the $1^{\text {st }}$ year, but in further years winter hardiness and sward cover are dependent on environmental conditions as well as the cultivar (Berzins et al., 2018 b). Average dry matter yield of the cultivars over four years varied from 6.12 to $7.65 \mathrm{t} \mathrm{ha}^{-1}$ with the 'Elena DS' producing a significantly higher yield. Average fresh weight of the tetraploid clones in two cuts varied from 1.08 to $1.76 \mathrm{~kg}$ per plant with the clone Vg149 producing significantly higher $(p<0.05)$ yield.

Intensive culm formation is characteristic of perennial ryegrass, and the cultivars were assessed to have medium to pronounced culm formation (scores ranged from 4.6 to 7.0). Variation between the tetraploid clones was higher with scores ranging from 3.3 to 8.0, which could be a result of them being assessed for only two seasons or possibly due to higher variation for this trait between the clones. It must be noted that results for the cultivars and clones cannot be compared directly, as the cultivars were assessed in sown sward, while the clones were assessed as individual plants. Therefore, an overall assessment was done of the clones, based on a range of indicators. Scoring was done in a range of 1 to 9 with 1 indicating that the clone was very weak and damaged, and 9 indicating that the clone was exceptional. Clone $\mathrm{Vg} 169$ received the best rating.

Significant differences in rust resistance were found between the cultivars and even more pronounced differences between the clones. However, average rust resistance scores over the years did not show such pronounced differences with scores ranging from 5.9 to 6.6 for cultivars and from 4.5 to 6.9 for the tetraploid clones. As mentioned previously, rust races can differ between years, and different genotypes can have differing resistance to various rust races. The identification and selection of rust-resistant individuals as well as the development of rust-resistant populations is one of the important tasks of perennial ryegrass pre-breeding activities.

One of the main disadvantages of perennial ryegrass is low persistence. Therefore, it is important to assess and select germplasm in varying environmental conditions with individuals being subjected to various stresses. In the autumn of the $4^{\text {th }}$ ley year, persistence of the cultivars ranged from $25 \%$ to $60 \%$ with the Latvian cultivar 'Spidola' showing significantly higher $(p<0.05)$ persistence (a score of 5.8), which is probably a reflection of this cultivar being well adapted to specific local growing conditions in Latvia.

Similarly to the assessment of agronomic properties, genetic analyses were done on 12 individuals from each of five cultivars, but only one individual of each selected tetraploid clone (Table 4). The mean number of alleles (over all loci) in each cultivar was approximately 4 and in most cases was over 1 in the clones. As perennial ryegrass is an outcrossing species, some level of genetic variation is expected even in cultivars. The mean number of effective alleles in the cultivars was lower than that indicating that some of the alleles were of low frequency. The presence of low frequency alleles within cultivars is also reflected in the mean frequency of the unique alleles found in the cultivars. All cultivars had unique alleles ranging from 1 to 5 in each cultivar, but they were of

Table 4. Genetic parameters of perennial ryegrass cultivars and tetraploid clones

\begin{tabular}{|c|c|c|c|c|c|}
\hline $\begin{array}{l}\text { Cultivar } \\
\text { and clone }\end{array}$ & $\begin{array}{l}\text { Number of } \\
\text { analysed } \\
\text { individuals }\end{array}$ & $\begin{array}{c}\text { Mean number } \\
\text { of alleles } \\
\text { over all loci (SE) }\end{array}$ & $\begin{array}{c}\text { Mean effective number } \\
\text { of alleles } \\
\text { (SE) }\end{array}$ & $\begin{array}{l}\text { Observed } \\
\text { heterozygosity } \\
(\mathrm{SE})\end{array}$ & $\begin{array}{l}\text { Total number } \\
\text { of unique alleles } \\
\text { (mean freq.) }\end{array}$ \\
\hline Elena DS & 12 & $4.29(0.84)$ & $2.50(0.26)$ & $0.53(0.09)$ & $5(0.07)$ \\
\hline Gunta & 12 & $4.14(0.51)$ & $2.68(0.44)$ & $0.45(0.08)$ & $4(0.10)$ \\
\hline Raite & 12 & $3.57(0.57)$ & $2.41(0.39)$ & $0.49(0.13)$ & $1(0.04)$ \\
\hline Raminta & 12 & $4.00(0.69)$ & $2.54(0.30)$ & $0.60(0.13)$ & $3(0.04)$ \\
\hline Spidola & 12 & $4.00(0.53)$ & $2.61(0.36)$ & $0.56(0.11)$ & $4(0.07)$ \\
\hline as $204 \mathrm{~s} 0$ & 1 & $1.00(0.22)$ & - & $0.14(0.14)$ & $2(0.50)$ \\
\hline $\operatorname{vg} 169$ & 1 & $1.57(0.30)$ & - & $0.71(0.18)$ & 0 \\
\hline vs $144 \mathrm{~s} 0$ & 1 & $1.29(0.29)$ & - & $0.43(0.20)$ & 0 \\
\hline vs26 & 1 & $1.29(0.29)$ & - & $0.43(0.20)$ & $1(0.50)$ \\
\hline vs 149 & 1 & $1.43(0.20)$ & - & $0.43(0.20)$ & 0 \\
\hline vs 213 & 1 & $1.43(0.20)$ & - & $0.43(0.20)$ & 0 \\
\hline
\end{tabular}


low frequency (mean frequency of unique alleles per cultivar was $<0.1$ ). This is probably again a result of the outcrossing nature of perennial ryegrass with a low level of gene flow from other perennial ryegrass germplasm. Unique alleles were also found in the tetraploid clones -1 in vs 26 and 2 in as204s0. All of the unique alleles in the tetraploid clones were heterozygous, i.e. not fixed.

The majority of analysed perennial tetraploid cultivars were genetically similar with only the 'Spidola' clustering separately. The analysed tetraploid clones clustered separately and had larger pairwise genetic distances (Fig. 2).

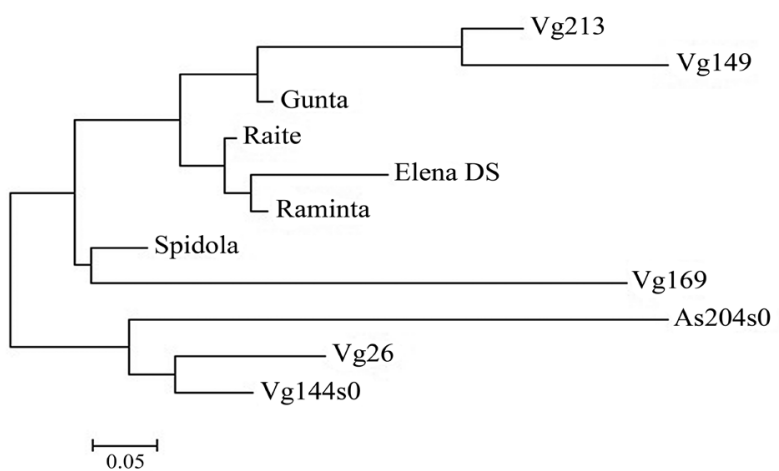

Figure 2. UPGMA dendrogram of Nei genetic distances between analysed perennial ryegrass cultivars and clones

This could partly be due to the fact that only one individual was analysed per clone; however, the clustering indicated that these clones were genetically distinct from the analysed cultivars.

\section{Conclusions}

1. The phenotypic assessment of tetraploid perennial ryegrass clones provided valuable information about novel genotypes with very varying properties. Preliminary evaluations show that tetraploid clones could be a valuable source for improving perennial ryegrass winter hardiness as well as rust resistance, which are important indicators for the Northern European region.

2. The genetic analyses indicated that the new tetraploid perennial ryegrass clones are distinct from cultivars developed in the Baltic countries, suggesting that there is sufficient diversity in the artificially generated tetraploid germplasm to provide valuable material for further breeding efforts.

3 . The evaluation of tetraploid clones should be continued, because very important step is progeny assessment to determine the heritability of traits. It could help in the future to develop diverse populations with different earliness, growing type, etc. for various uses and conditions.

\section{Acknowledgements}

This study was carried out in frameworks of the project "Assessment of pre-breeding material of perennial ryegrass" funded by the Latvia Ministry of Agriculture and Latvia University of Life Sciences and Technologies implementation of the LLU research program project "Agro-ecological assessment of varieties and gene bank accessions of perennial ryegrass in Latvia condition".

\section{References}

Aavola R. 2005. The yield potential of Estonian perennial ryegrass (Lolium perenne) cultivars at different mineral fertilization levels and cutting frequencies. Grassland Science in Europe, vol. 10, p. 449-453.

Berzins P., Jansone S., Rancane S., Stesele V., Dzene I. 2015. The evaluation of perennial grass cultivars in Latvia condition. Proceedings of the $25^{\text {th }} \mathrm{NJF}$ congress Nordic View to Sustainable Rural Development, p. 141-147.

Berzins P., Rancane S., Stesele V., Vezis I. 2018 (a). Performance of Lolium spp., Festuca spp. and their mutual hybrids in Latvian conditions. Grassland Science in Europe, vol. 23, p. $123-125$.

Berzins P., Rungis D., Rancane S., Gailite A., Belevica V., Stesele V., Vezis I., Jansons A. 2018 (b). Yield and genetic composition of Latvian $\times$ Festulolium cultivars and breeding material. G. Brazauskas et al. (eds). Breeding Grasses and Protein Crons in the Fra of Genomics. Snringer, p. 62-67. https://doi.org/10.1007/978-3-319-89578-9 11

Berzins P., Kungis D., Kancane S., Stesele V., Vezis I., Jansons A. 2019. Genetic and agronomic analysis of Latvian fescue (Festuca spp.), ryegrass (Lolium spp.) accessions and their hybrids. Proceedings of the Latvian Academy of Sciences. Section R. Natural, Exact and Annlied Sciences, 73 (6): 487-493. https://doi.org/10.2478/prolas-2019-0075

Dabkevičienè G. 2009. In vitro methods in clover aliopolypioidy Zemdirbyste-Agriculture, 96 (1): 191-204.

Deleuran L. C., Boelt B. 2009. Establishment techniques in under-sown perennial ryegrass for seed production, Acta Agriculturae Scandinavica, Section B: Soil and Plant Science $59(1) \cdot 57-6)$ https://doi.org/10.1080/09064710701855221

Felsenstein J. 198Y. PHYLIP - Phylogeny Inference Package (version 3.2). Cladistics, 5: 164-166.

Grogan D., Gilliland T. J. 2011. A review of perennial ryegrass variety evaluation in Ireland. Irish Journal of Agricultural and Food Research, 50: 65-81.

Helgadóttir Á., Frankow-Lindberg B. E., Seppänen M. M., Søegaard K., Østrem L. 2014. European grasslands overview: Nordic region. Grassland Science in Europe, vol. 19 , p. $15-28$.

Helgadóttir A., Marum P., Persson C., Isolathi M., Aavola R., Rognli O.A. 2016. New cultivars needed to ensure survival of perennial ryegrass across the northern region. Grassland Science in Europe, vol. 21, p. 868-870.

Helgadóttir Á., Aavola R., Isolahti M., Marum P., Persson C., Aleliūnas A., Brazauskas G., Krisjánsdóttir T. A., Asp T. 2018. Adaptability and phenotypic stability of Lolium perenne L. cultivars of diverse origin grown at the margin of the species distribution. Journal of A ornnomy and Cron Science, 204 (5): 493-504. https://doi.org/10.1111/jac.12273

Jørgensen M., Leraand M. K., Ergon Å., Bakken A. K. 2019. Effects of including perennial ryegrass (Lolium perenne L.) in different species mixtures on yield, feed quality and botanical composition in first year of ley. Grassland Science in Europe, vol. 24, p. 152-154.

Kemešytè V., Statkevičiūtè G., Aleliūnas A., Brazauskas G 2016. Variation for plant architecture traits within a perennial ryegrass association mapping population. Roldán-Ruiz I. et al (eds). Rreeding in a World of Scarcity. Snringer, p. 41-45. https://doi.org/10.1007/978-3-319-28932-8 6

Kemešytè V., Statkevičiūte G., Jaśkūne K. 20̄19. Long-term crown rust survey in perennial ryegrass and Festulolium trials in Lithuania. Grassland Science in Europe, vol. 24, p. 429.

Lee M. A., Howard-Andrews V., Chester M. 2019. Resistance of multiple diploid and tetraploid perennial ryegrass (Lolium perenne L.) varieties to three projected drought scenarios for the IIK in 2080 A oronomy 9. 1-7. https://doi.org/10.3390/agronomy9030159

Lemeżıene N., Kanapeckas J., larakanovas P., Nekrošas S. 2004. Analysis of dry matter yield structure of forage grasses. Plant, Soil and Environment, 50: 277-282. https://doi.org/10.17221/4033-PSE

McLonagh J., U' Uonovan M., McEvoy M., Gilliland T. J. 2016. Genetic gain in perennial ryegrass (Lolium perenne) varieties 1073 to 2013 Funhvtica 217. 187-199. https://doi.org/10.1007/s10681-016-1754-7

Østrem L., Volden B., Larsen A. 2013. Morphology, dry matter yield and phenological characters at different maturity stages of $\times$ Festulolium compared with other grass species. Acta Agriculturae Scandinavica, Section B: Soil and Plant Science $63(6) \cdot 531-542$

https://doi.org/10.1080/09064710.2013.819440 
Østrem L., Helgadóttir Á., Niemeläinen O., Seppänen M., Pedersen M. G., Halling M., Rognli O. A. 2015 (a). Environmental impact on winter survival and production in non-native grasses in the Nordic countries. Proceedings of the $25^{\text {th }} \mathrm{NJF}$ congress Nordic View to Sustainable Rural Development, p. 127-133.

Østrem L., Rapacz M., Larsen A., Dalmannsdottir S., Jørgensen M. 2015 (b). Influences of growth cessation and photoacclimation on winter survival of non-native LoliumFestuca grasses in high-latitude regions. Environmental and Fxnerimental Rotany 111. 21-31 https://doi.org/10.1016/j.envexpbot.2014.10.008

Peakall R., Smouse P. E. 2006. GENALEX 6: genetic analysis in Excel. Population genetic software for teaching and research Molecular Fcolnov Notes 6 (1) . 288-795. https://doi.org/10.1111/j.14̌̈1-8286.2005.01155.x

Porebsk1 S., Bailey L. G., Baum B. R. 1997. Modification of a CTAB DNA extraction protocol for plants containing high polysaccharide and polyphenol components. Plant Molecular Binlogy Renorter. 15: 8-15. https://doi.org/10.1007/BF02772108

Rancane S., Berzins P., Vezis 1., Jansons A., Rebane A., Stesele V. 2019. Pre-breeding activities in Lolium perenne. Scientific-practical conference Lidzsvarota Lauksaimnieciba. Jelgava, Latvia, p. 56-61.

Reheul D., Ghesquiere A. 2006. Breeding perennial ryegrass with better crown must resistance Plant Rreeding 115 (6) 465-469. https://doi.org/10.1111/j.1439-0523.1996.tb00958.x

Rognli O. A., Larsen A. S., Nielsen N. C., Helgadóttir Á., Aavola A., Persson C., Isolahti M., Asp T., Marum P. 2013. The Nordic Public-Private Partnership (PPP) for pre-breeding in perennial ryegrass (Lolium perenne L.). Grassland Science in Europe, vol. 18.

Rognli O. A., Aavola R., Aleliūnas A., Asp T., Brazauskas G., Gylstrøm K. H., Helgadottir A., Isolahti M., Kovi M. R., Kristjánsdóttir A., Larsen A. S., Marum P., Paina C., Persson C., Rancãne S. 2018. Utilization of genebank accessions to improve northern adaptation of perennial ryegrass. G. Brazauskas et al. (eds.). Breeding Grasses and Protein Crons in the Fra of Cenomics. Snringer, p. 3-8. https://doi.org/10.1007/978-3-319-89578-9 1

Schubiger F. X., Baert J., Bayle B., Bourdoñ P., Cagas B., Cernoch V., Czembor E., Eickmeyer F., Feuerstein U., Hartmann S., Jakesova H., Johnston D., Krautzer B., LeenheerH., Lellbach H., Persson C., Pietraszek W., Posselt U. K., Romani M., Russi L., Schulze S., Tardin M. C., VanHee F., Kruijssen L., Wilkins P., Willner E., Wolters L., Boller B. 2010. Susceptibility of European cultivars of Italian and perennial ryegrass to crown and stem rust. Euphytica, 176: 167-181.

Studer B., Asp T., Frei U., Hentrup S., Meally H., Guillard A., Barth S., Muylle H., Roldán-Ruiz I., Barre P., KoningBoucoiran C., Uenk-Stunnenberg G., Dolstra O., Skøt L., Skøt K. P., Turner L. B., Humphreys M. O., Kölliker R., Roulund N., Nielsen K. K., Lübberstedt T. 2008. Expressed sequence tag-derived microsatellite markers of perennial ryegrass (I.nlium norenne I.) Molecular Rreeding, ?1 (4): 533-548. https://doi.org/10.1007/s11032-007-9148-0

UPOV. 2006. Guidelines for the conduct of tests for distinctness, uniformity and stability. http://www.upov.int/edocs/tgdocs/ en $/ \operatorname{tg} 004 . d o c$

Westermeier P., Hartmann S. 2019. Comparing drought tolerance between isogenic di- and tetraploid perennial ryegrass (Lolium perenne L.) genotypes. Grassland Science in Europe, vol. 24, p. 435.

Westermeier P., Albrecht T., Geyer R., Willner E., Hartmann S. 2019. Analysis of drought tolerance in perennial ryegrass (Lolium perenne L.) with methods of genomic prediction. Grassland Science in Europe, vol. 24, p. 421-423.

Wilkins P. W., Humphreys M. O. 2003. Progress in breeding perennial forage grasses for temperate agriculture. The Inurnal of A gricultural Science. 140 (2): 129-150. https://doi.org/10.1017/S0021859603003058

WRB. 2014. World reterence base tor soll resources. World Soil Resources Reports No. 106. FAO, 189 p.

\title{
Lolium perenne tetraploidinių klonų, sukurtụ iš skirtingos diploidinès selekcinės populiacijos, ịvertinimas
}

\author{
S. Rancāne ${ }^{1}$, D. E. Ruṇgisis ${ }^{2}$ D. Kreišmane ${ }^{3}$ I. Vēzis ${ }^{1}$, A. Rebāne ${ }^{1}$, A. Jansons ${ }^{1}$ \\ ${ }^{1}$ Latvios gyvybės mokslų ir technologijų universiteto Žemès ūkio tyrimų institutas \\ ${ }^{2}$ Latvios valstybinis miškų tyrimų institutas "Silava" \\ ${ }^{3}$ Latvijos gyvybės mokslų ir technologijų universiteto Žemės ūkio fakultetas
}

\section{Santrauka}

Daugiametė svidrè (Lolium perenne L.) yra viena svarbiausių pašarinių žolių, duodanti dideli derliu ir puikios kokybės pašarą. Pagrindinis daugiametès svidrès auginimo ploto Šiaurès ir Baltijos regione ribojimo veiksnys yra nepakankamas atsparumas žiemojimui dẻl nestabilaus klimato, taip pat nepakankamas išsilaikymas žolyne ir atsparumas sausrai. Śiuo metu daugiametès svidrès veislių genetinè ịvairovẻ yra palyginti ribota, todèl kintančio klimato kontekste labai svarbu sukurti naują, lengvai pritaikomą genetinę medžiagą.

Vykdant Šiaurès ir Baltijos šalių viešojo bei privataus sektoriaus partnerystės projektą, daugiametės svidrès selekcijos pradiniame etape 250 tetraploidinių augalų (toliau - genotipu), sukurtų Lietuvos agrariniu ir mišku mokslų centro Žemdirbystės institute chromosomoms padvigubinti panaudojus kolchiciną, buvo įvertinti lauko sąlygomis Latvijos gyvybės mokslų ir technologijų universiteto Žemès ūkio tyrimų institute. Išsamus fenologinis visų genotipų ịvertinimas buvo atliktas per trejus (2016-2018) metus. Duomenims analizuoti augalai buvo sugrupuoti pagal plaukejjimo laiką ir augimo pobūdị. Grupès reikšmingai skyrèsi pagal atsparumą žiemojimui, ataugimo greitị, generatyvinių ūglių vystymosi greitị, jautrumą rūdims ir kt. Antraisiais tyrimo metais buvo surinkta gerai išsilaikiusių augalų, pasižyminčių perspektyviomis savybėmis, sẻkla - iš viso 199 genotipų, arba 358 augalų (atitinkamai 80 ir $48 \%$ visų tirtų augalų). Atsitiktinai parinktų genotipų, pasižyminčių didžiausiu ir mažiausiu atsparumu žiemojimui, genotipavimo rezultatai parodè, kad klonai genetiškai skyrėsi nuo Baltijos šalyse sukurtų veislių - tetraploidiniuose klonuose buvo rasti unikalūs aleliai, kurių neturèjo analizuotos veislès.

Tyrimo rezultatai rodo, kad sukurti tetraploidiniai klonai arba genotipai galètų būti vertinga selekcinè medžiaga, siekiant ateityje pagerinti daugiamečių žolių veislių tinkamumą vietinèms aplinkos sąlygoms.

Reikšminių žodžiai: DNR žymekliai, genotipas, daugiametė svidrè, fenotipavimas, pradinè selekcija, veislè. 